\title{
How to Create a Great Monastery: Xuanzang's Foundation Legend of Nālandā in Its Indian Context
}

\author{
MAX DEEG \\ Cardiff University \\ DeegM1@cardiff.ac.uk
}

Abstract: Xuanzang's Datang Xiyu ji has been and is notoriously used for the reconstruction of South Asian history and the history of Buddhism in India. Very often Xuanzang's information is either dismissed because it does not corroborate or even contradicts the 'facts' in Indian sources (epigraphic or literary sources), or is used to overwrite these sources. Both approaches usually do not take into account the wider context in which the different sources are situated. This paper will take up as a case study Xuanzang's description of the foundation of Nālandā Mahāvihāra through the Gupta kings and the available South Asian material to show how a comparative analysis can lead to a new approach to the Datang Xiyu ji as a source for the study of cultural history instead of reading it exclusively in a simplistically and uncritically positivist way.

Keywords: Xuanzang, Nālandā, Mañjuśrimūilakalpa, Vasubandhu, Gupta, foundation story, genealogy

DOI: https://dx.doi.org/10.15239/hijbs.03.01.07 


\section{Inscription overrules anything else!}

This could be the conclusion when reading scholarly literature about Indian history, particularly of dynastic and political history. Admittedly, inscriptions have been important from the very beginning of historical research on the Indian subcontinent, reaching as far back as the beginning of the nineteenth century when the inscriptional material found on coins and other artefacts could be read due to the decipherment of the Brāhmī script through James Prinsep (1799-1840), and others, and the fanciful dynastic family trees found in the Purānas were replaced by more accurate and reliable material which reflected rather the self-identity of the rulers than later and idealized lineages.

A good example for the absolute predominant treatment of inscriptions in the sense of my introductory statement, which at the same time introduces my own sources, is given by the famous Indologist Ramachandra Narayan Dandekar in his well-known History of the Guptas (1941). Dandekar first states: '[The] sources are mainly of three kinds-literary, epigraphic and numismatic'. ${ }^{1}$ Of the first group he is quite skeptical and displays a certain bias in favour of Indian sources:

Among the literary sources referring to the history of the Guptas, mention must first of all be made of the Purānas, which form perhaps the only source providing any information regarding the origin and the earlier exploits of this illustrious dynasty. We have, however, to utilise the Purānas, in this connection, subject to certain reservations, because these literary works are generally characterized by some serious defects from the historical point of view, such as, the absence of dates, the lack of general agreement among themselves, and their usual tendency to treat contemporary dynasties as successive. ... The momentous discovery of 'Mañju-śri-mūlakalpa' (...), a remarkable Mahāyāna chronicle of the succession of imperial powers in India, from 700 B.C., to 750 A.D., without a break, has

1 Dandekar, History of the Guptas, 1. 
adequately supplied the account of the Early Gupta and Later Gupta periods, which had been a blank in the history of ancient India so far written. In addition to these and other Indian texts, we possess the very interesting account of the travels of $\mathrm{Fa}$ Hein [sic!] and Hiuen Tsang, the two Chinese pilgrims, who visited India in the 5th and the 7th centuries A.D., respectively. ${ }^{2}$

Dandekar then starts a long discussion of the second and third strand of sources with the following remarks:

Far more useful and reliable than the literary sources are the archaeological sources, mainly consisting of inscriptions and coins, belonging to the Gupta period, the discovery, publication, and historical interpretation of a large number of which worthily stand to the credit and amply testify to the industry and the historical acumen of several scholars, ... ${ }^{3}$

I would turn my eyes now to the sources which Dandekar calls 'addition' to the other Indian sources and 'very interesting accounts'. I will show that these, particularly Xuanzang's 玄牀 (c. 602-664) Datang Xiyu ji 大唐西域記 [Record of the Western Regions from the Great Tang (Dynasty)], should be studied in their own right and not only as appendices, where suitable, to inscriptional and other Indic sources and for the purpose of reconstructing positive history, in most cases consisting of the study of dynastic lineages and inter-dynastic conflicts. Although Xuanzang gives information about Indian rulers, his motivation certainly is not to present dynastic history and lineage.

I have dealt elsewhere in detail with an example of Xuanzang's dynastic narrative of the contemporary Indian ruler Harșavardhana Śilāditya. ${ }^{4}$ This narrative is partly corroborated by the inscriptions and by a rare example of Indian 'biography', Bāṇa's Harṣacarita; it

2 Dandekar, History of the Guptas, $1 \mathrm{ff}$.

3 Dandekar, History of the Guptas, 3.

4 Deeg, 'The Political Position of Xuanzang'. 
does, however, also show differences with the dynastic lineage presented by Harșa in his own inscriptions.

In the opinion of scholars, the inscriptions would overrule the 'Record': since neither the length of the lineage nor the religious affiliation of the rulers given by Xuanzang fit the inscriptional material, Xuanzang's witness is usually dismissed as faulty. While this may be acceptable for an epigraphist and historian of India who is only interested in the dynastic history the Indic sources normally can deliver, the historian of Buddhism may (and should) not be happy to discard the given information that easily. It seems legitimate to ask the question of why these differences exist. After all, self-reflective and -constructed dynastic lineages are not equivalent to positive history. One may even go so far as to question the higher degree of reliability of inscriptional lineages in the light of the problems in details scholars encounter in their interpretation. On the other hand, the Buddhist sources may not only reflect a somewhat biased, idealized, and historically distorted viewpoint, but may, in fact, contribute to the understanding of other historical sources.

Harṣa Śîlāditya's Pusyabhūti lineage, however, as I have concluded, was 'streamlined' by Xuanzang to match the dynastic lineage of the Tang. Since the Tang were only in the second generation of rulers, Taizong 太宗 (599-649, r. from 626) having assumed power from his father, Gaozu 高祖 (566-635, r. 618-626), after killing his brother, crown-prince Li Jiancheng 李建成 (589-626), the Indian dynasty could not possibly be presented with a longer lineage than the Chinese dynasty and was therefore reduced to the same structure and length as the Tang.

I think the answer to the question of historical reliability and credibility in the case of Xuanzang's description of Indian 'history' lies in the context of the 'Record'. As I have tried to show on different occasions, Xuanzang wrote for the Tang emperor Taizong and tried to educate him by presenting an idealized Indian and Buddhist world. Rulers (e.g. Aśoka ${ }^{5}$ ) and rulership played an important role

5 The example of the narrative of Aśoka and Kunāla is discussed in Deeg, 'Show Me the Land Where the Buddha Dwelled', 103ff. 
in this 'educational program', 6 and were presented as idealized and paradigmatic Buddhist kings.

In order to substantiate this view and interpretation, I will contextualize the foundation story of Xuanzang's own 'home' monastery in India, Nālandā Mahāvihāra, ${ }^{7}$ given in the 'Record' according to which rulers of the Gupta dynasty supported Buddhism over generations, leading the monastery to its actual importance and greatness at the time when Xuanzang was residing and studying there. In other words, the original function of giving a successive line-up of Gupta rulers, patrons and donors who made Nālandā great in what we may assume as Xuanzang's Buddhist source was to give the monastery political legitimation. Xuanzang then uses this narrative for his own educational purpose to show the Chinese emperor how a great monastery should be founded and sustained by royal or imperial support:

Going more than thirty miles from there (i.e. Rājagṛha) in northern [direction one] arrives at the monastery of Nalantuo ${ }^{8}$ (in the language of the Tang [this is] 'Giving-Not-Enough'). [One can] hear old people say that south of this monastery, in a mango-grove, there is a lake, and the nāga in it is called Nàlanda, and because the monastery was built close to it, it has received its name. [But] as a matter of fact [it is because] the Tathāgata in the past, [when he] practiced the Bodhisattva path and was the king of a great kingdom, was compassionate with the living beings and found pleasure in giving

6 Deeg, 'Writing for the Emperor'.

7 On the question of the historical origin of Nālandā and the Chinese sources about the monastery see Deeg, 'Setting the "Records” Straight'. I was not able to consult Prasad, Nalanda, its Mahāvihāra and Xuan Zang, but suspect that no real new contribution to our problem is contained in that publication.

8 那爛陀/*na'-lan ${ }^{b}-d a$ (all EMC reconstructed forms are marked by * and are taken from Pulleyblank, Lexicon of Reconstructed Pronunciation in Early Middle Chinese, Late Middle Chinese, and Early Mandarin), Skt. Nālanda, Ch. Shiwuyan 施無厭. The name is etymologized as Skt. na (wu 無) + alam (yan 厥) $+\sqrt{ } d \bar{a}-(s h i$ 施). 
generously, [so that people] praised [him] for [his] virtue and called [him] 'Giving-Not-Enough'. And from [this name] the monastery received its name.

This land originally was a mango-garden [which] five hundred merchants bought for one billion gold coins in order to donate it to the Buddha. There the Buddha preached the dharma for [a period] of three months, and all the merchants realized the fruit of sainthood. Not long after the nirvanna of the Buddha, the former king of this kingdom, Shuojialuoadieduo' (in the language of the Tang [this is] 'Ruler-Sun'), honored the One Vehicle, venerated the Three Jewels, formally declared [this] a site of merit ${ }^{10}$ and built this monastery. [When] the construction work was begun, the body of the nāga was pierced. A niqian-heretic, ${ }^{11}$ who was good at divination, saw [this] and recorded: ${ }^{12}$ 'This is a sacred place, [and] the monastery built [here] will certainly be prospering and will become a model for

9 鑠迦羅阿迭多/ ${ }^{*} 6 i a k-k i a-l a-P a-d \varepsilon t-t a$, Skt. Śakrāditya, Ch. Diri 帝日. The transliteration of the names of the king displays some deficiencies, as here in this case and in Bālāditya (note 9; see also Sīlāditya) the two akșaras/syllables -ditya are rendered as if the pronunciation of the underlying name had been *-ditta, as reconstructed by Mizutani, Daitō-saiiki-ki, 163, note 2. I have no explanation for this form (see also below the transliteration of Kumārāditya in Paramārtha's biography of Vasubandhu); the underlying Indic cannot be a Prakrit form of -ditya which would be *-dic(c)a (see Pāli ädicca, or Ārdhamāgadhī äicca: Ratnacandraji, An Illustrated Ardha-Magadhi Dictionary, 3b): see von Hinüber, Das ältere Mittelindisch im Überblick, 192, \$247. See also below, note 13, the remark on the -gupta names.

10 shizhan fudi 式占福地: I do not take zhan 占 here in the meaning of 'divinizing' (Li, The Great Tang Dynasty Record, 281), but in its secondary meaning of ( $H D C$, s.v.); fudi 福地 here probably has a double connotation, the concrete one of the place and another one of 'field of merit' (Skt. punyakșetra).

11 niqian-waidao 尼乾外道: niqian 尼乾/*nri-gian, stands for ni(r)gran(tha), and the term means a Jain.

$12 j i$ 記: it is difficult to say in which form this was supposed to have been done in an Indian context: it could be in written form, and this seems to be meant here. 
the monasteries in the Five Indias. It will be thriving more than one thousand years. Scholars joining it in the future will easily succeed in [their] work, but [they] often will spit blood, because the nāga has been damaged'.

[Śakrāditya's] son Fotuojuduo ${ }^{13}$ (in the language of the Tang [this is] 'Awakened-Protection') followed [him] on the throne and continued [his] superb work, and built [another] monastery further to the south of the [former] one.

King Datajieduojuduo ${ }^{14}$ (in the language of the Tang [this is]

13 佛陀䊝多/*but-da-kuwk-ta, Skt. Bu(d)dhagupta, Ch. Juehu 覺護. The name *Buddhagupta seems to be a 'buddhisized' form for the Budhagupta of the inscriptions and there is no need to correct the inscriptional name on the basis of Xuanzang. The transliteration of the name element -gupta as EMC *kuwk-ta is odd. Older, phonetically more suitable transliterations of the name element -gupta were well known: Dharmagupta/Tanmojueduo 昙摩崛多/*dam-magut-ta (probably Pkt. Dhammagutta) (fl. 384-417), Dharmagupta/Damojiduo 達摩笈多/*dat-ma-gtap-ta (fl. ca. 590-619)-but see in Huijiao’s Gaoseng zhuan [Biographies of Eminent Monks]: Tanwujuduo 曇無迷多 for Dharmagupta (T no. 2059: 403a.23-24) -Jñānagupta/She'najueduo 闍那崛多/*dziana'-gut-ta (probably Pkt. Jānagutta) (523-600). Other characters or syllables would have been more suited to represent the final - $p$ of gupta: e.g. jia 萊, 煩, 鋏, et.al./*ksp, jie 劫/*kiap, etc. On the other hand the transliteration juduo 迷 多 for gupta was already in use, as for instance in Aśvaghoṣa’s Kalpanāmanditikā (Sūtrālamkāraśāstra, Da zhuangyan lunjiing 大莊嚴論經), translated by Kumārajīva ( $T$ no. 201, passim: Youbojuduo 優波釆多 for Upgupta, or Shilijuduo 尸利毱多 for Śrīgupta), or the Ayu wang zhuan 阿育王傳 [Biography of King Aśoka], translated by An Faqin 安法欽 (fl. 281-306) (T no. 2042, passim:

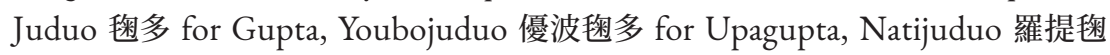
多 for Nadigupta). Despite its shortcoming Xuanzang seems to follow this established transliterational tradition-followed e.g. by Śikṣānanda (652-710) for the Gupta dynasty in his translation of the Lainkāvatārasūtra (T no. 672: 638b.16)—-when he himself renders names like Śrīgupta (Shilijuduo 室利迷多), Upagupta (Wubojuduo 䣕波楼多), or Dharmagupta(ka)-nikāya (Damojuduo bu 達摩钩多部) in the Datang Xiyu ji and in his translations of Abhidharma texts ( $T$ no. 1545 , $T$ no. 1558 , and $T$ no. 1562). 
'Thus-Come') seriously practiced [like his] predecessors, and built [another] monastery further to the east of the [former] one.

When King Poluoadieduo ${ }^{15}$ (in the language of the Tang [this is] 'Infant-Sun') ascended the throne, [he] built [another] monastery further to the northeast of the [former] one. After these matters were achieved, [the king summoned] an assembly of merit ${ }^{16}$ to offer congratulations, showed sincerity to this world and to the yonder world, and invited commoners and saints. For this assembly monks from the Five Indias, from tens of thousands of miles [away], flocked together like clouds. When the community was finally seated, two arrived late, and were led into the third floor of a pagoda. Some [of the others] asked: '[When] the king wanted to set up the assembly, [he] first invited commoners and saints; where are [you] bhandantas from [that you] arrived as the latest?' [They said]: 'We [are from] the kingdom of Zhina. ${ }^{17}$ [Our] master ${ }^{18}$ [is suffering] from infant measles ${ }^{19}$ when [he] just had eaten [his] meal, [he] received the king's invitation from afar; therefore [we] came to attend the assembly'. The ones [who] had asked were startled and quickly told the king [about this]. In [his] mind the king knew that [they] were saints, and [he] went himself to ask them. [But since he] went up to the pagoda too late, nobody knew where [they] had left for. The king gained deep faith, gave up [his] kingdom and left the household..$^{20}$ After [he]

14 呾他揭多迷多/*tat-tha-kiat-ta-kuwk-ta, Skt. Tathāgatagupta, Ch. Rulai 如 來: the translation of the name is incomplete and should rather be Rulaihu 如來 護 (Mizutani, Daitō-saiiki-ki, vol. 3, 164, note 5; Ji, Datang Xiyu ji jiaozhu, 755, note 4). In Xuanzang's biography the name is shortened to Tathāgata: Datajieduo 怛他揭多/Rulai 如來 (T no. 2053, 237b.11-12).

15 婆羅阿迭多/*ba-la-Pa-det-ta, Skt. Bālāditya, Ch. Youri 幼日.

16 fubui 福會, Skt. * punyaparișad.

17 至那 ${ }^{*}{ }^{*} 6 i^{b}-n a$ ', Skt. Cīna.

18 beshang 和上/* ${ }^{*} w a-d z i a \eta '$, originally a transliteration of ācārya and here used in this sense.

19 yingzhen 嬰疹; or, with the variant reading yingji 嬰疾, some skin disease (s. $H D C$, s.v. yingji).

20 chujia 出家, i.e. he became a novice (took the pravrajyā). 
had left the household, [he] was positioned at the [lower] end of the monks' community, ${ }^{21}$ was constantly in a disgruntled state of mind and felt not very happy [saying]: 'Formerly I was the king and [held] the most respected and highest position, [but] now [that I] have left the household [I] am the [most] inferior at the lower [end] of the monks' community!' [He] went to the community [of monks] and told [them the] situation [he was in]. Thereupon the community agreed that those who had not taken the [full] precepts ${ }^{22}$ could establish [their] position according to [their] age. Therefore, only this monastery has this regulation. ${ }^{23}$

After the son of this king, Fasheluo ${ }^{24}$ (in the language of the Tang [this is] 'Diamond Bolt'), had ascended the throne, [his] faith

21 seng 僧, here corresponding to Skt. sangha. The full term here is sengmo 僧 末. The latter term occurs in connection with two young novices (shami 沙爾) in the Aśokāvadāna (Ayu wang jing 阿育王經 [Sūtra of King Aśoka], T no. 2043: 141a12) there as zhongsengmo 眾僧末, and in the legend about a monkey and five hundred rssis (xianrenshi 仙人師) in Jinglü yixiang 經律異相 [Differences and Similarities in the Sütras and Vinayas] (T no. 2121: 47.252a10).

22 weishoujie zhe 未受戒者, lit.: 'who has not yet taken the precepts (silla)', Skt. anupasampada.

23 There is, of course, no historical evidence of the described events-monks from China and a Gupta-king retiring as a monk. Xuanzang may have had access to a Buddhist version of a regional historiography of the Nālandā-monastery, and that also may explain the Buddhisized version of the kings' names.

24 伐闍羅/*buat-dzia-la, Skt. Vajra, Ch. Jin'gang 金剛; could this be an abbreviated form of an unattested *Vajragupta or *Vajrāditya (see below)? Xuanzang uses this transliteration in a short text for an arbat called Vajraputra (Fasheluofuduoluo 伐闍羅弗多羅). Nothing is known of a Gupta king of this name either from inscriptions nor coin legends. In the light of this lack of other sources the identification of Vajra with the va-kārākhya, '[king whose] name [starts] with va-', in Mañjuśrimülakalpa 53.779 (see below), as proposed by Jayaswal, An Imperial History of India, 55-56 and 67; and Raychaudhuri, Political History of Ancient India, 525, note 2, and followed by Mizutani, Daito-saiiki-ki, vol. 3, 164-65, note 7; and Ji, Datang Xiyu ji jiaozhu, 756, note 7, is at best hypothetical. According to the Mañjusirimülakalpa this king is the successor (anuja) of 
was really strong, and [he] also built a monastery to the east of the [former]. Later again [another] king of Central India built [another] monastery to the north of the [former]. Then [he] encompassed [everything] by a strong wall [with] one and the same gate [for all the monasteries]. Since continuous generations of rulers were [involved] in constructing activities and employed [all their] efforts in carving [stones for the buildings], [this] really is a magnificent view. A statue of the Buddha is nowadays placed in the first great monastery of 'Ruler-Sun', and each day forty different monks from the community go there and take [their] meal to pay back the favor of the donors ${ }^{25} \cdot{ }^{26}$

Prakațāditya (pa-kārākhya) and is ruling at the beginning of the kāliyuga as one of the last of his lineage.

25 shizhu zhi en 施主之恩.

26 Datang Xiyu ji, $T$ no. 2087, 51: 8.923b13-c19: 從此北行三十餘里, 至那 爛陀 (唐言施無厭) 僧伽藍。聞之者舊日 : 此伽藍南菴沒羅林中有池，其龍名那 爛陀，傍建伽藍，因取為稱. 從其實議，是如來在昔修菩薩行，為大國王，建都 此地，悲㟲眾生，好樂周給，時美其德，號施無厭. 由是伽藍因以為稱. 其地本 菴沒羅園，五百商人以十億金錢買以施佛。佛於此處三月說法，諸商人等亦證聖 果. 佛涅槃後未久，此國先王銯迦羅阿迭多(唐言帝日)敬重一乘，遵崇三寶，式 占福地，建此伽藍。初興功也，穿傷龍身. 時有善占尼乾外道見而記日：“斯 勝地也，建立伽藍，當必昌盛，為五印度之軌則，逾千載而彌隆. 後進學人，易 以成業，然多歐血，傷龍故也.'其子佛陀㲎多王(唐言覺護)繼體承統，聿遵勝 業，次此之南又建伽藍. 呾他揭多毛多王 (唐言如來) 篤修前緒，次此之東又建伽 藍. 婆羅阿迭多(唐言幼日)王之嗣位也，次此東北又建伽藍. 功成事畢，福會 稱慶，輸誠幽顯，延請凡聖. 其會也，五印度僧萬里雲集. 眾坐已定，二僧後至， 引上第三重閣。或有問日：“王將設會，先請凡聖，大德何方，最後而至?’日： “我至那國也. 和上嬰疹, 飯已方行, 受王遠請, 故來赴會.' 問者驚駭, 遽以白王. 王心知聖也, 身往問焉. 遲上重閣, 莫知所去. 王更深信, 捨國出家. 出家既已, 位 居僧末, 心常快快, 懷不自安 : ‘我昔為王, 尊居最上, 今者出家, 卑在眾末!’尋往 白僧，自述情事. 於是眾僧和合，令未受戒者以年齒為次. 故此伽藍獨有斯制. 其王之子伐闍羅(唐言金剛)嗣位之後，信心貞固，復於此西建立伽藍. 其後中印 度王此北復建大伽藍. 於是周垣峻峙, 同為一門. 既歷代君王繼世興建, 窮諸剞 片, 誠壯觀也. 帝日本大伽藍者, 今置佛像, 眾中日差四十僧就此而食, 以報施主 之恩. 
The unnamed king at the very end of the description should have been one of the rulers of the period between the decline of power and territory of the Guptas and Harșa's reign/Xuanzang's visit. He has been identified by some scholars as Yaśodharman ${ }^{27}$ who ruled in the first half of the sixth century, another rather unlikely identification being Sīlāditya of Kanauj. ${ }^{28}$

The successive lineage of rulers founding monasteries at Nālandā given by Xuanzang are clearly referring to the Guptas, but this is, as has been stated by several scholars when comparing it with the 'standard' dynastic genealogy extracted from Gupta inscriptions, puzzling and asks for explanation. Using the reconstructed Sanskrit names the direct dynastic lineage is as follows:

$$
\text { Śakrāditya-Bu(d)dhagupta-Tathāgatagupta-Bālāditya-Vajra }
$$

Anybody knowing anything about the Guptas will recognize one or two historical names, Budhagupta and Bālāditya, the latter being the epithet or biruda of Narasimhagupta.

For comparison I give the succession lineage of the Guptas as reconstructed, mutatis mutandis, by modern historians; kings are listed in sequence of their rule (with their epithets without taking into account the family relation): ${ }^{29}$

Abbreviated versions are found in Huili's 慧立 biography, the Datang Da Ci'en si sanzang fashi zhuan, 大唐大慈恩寺三藏法師傳 [Biography of the Tripițaka dharma master of the Great Cien Monastery of the Great Tang (Dynasty)] ('Biography') ( $T$ no. 2053: 237b.9ff.), and in Daoxuan’s 道宣 (596-667) Shijia fangzhi 釋迦方志 [Record of the Regions of Śākya(muni)] (T no. 2088: 964b.23ff).

27 For example, see Raychaudhuri, Political History of Ancient India, 525.

28 Heras, 'The Royal Patrons of the University of Nalanda', 13ff.; Kuwayama, 'How Xuanzang Learnt About Nālandā', 11.

29 Following Willis, 'Later Gupta History', 135, slightly more complex Bakker, 'A Theatre of Broken Dreams', 180; and Bakker, The World of the Skandapurāna, 27. Skandagupta may be inserted between Kumāragupta I and Purugupta: Tandon, 'The Succession After Kumāragupta I'. 
[Ghațotkaca mahārāja-Candragupta I mahārājādhirājaSamudragupta mahārājādhirāja dauhitra-Candragupta II paramabhāgavata vikramāditya-] Kumāragupta I mahäräjädhirāja mahendräditya-Purugupta mahāaājādhirāja-Narasimhhagupta bāläditya paramabhägavata-Budhagupta paramadaivata mahāräjädhirāja-Kumāragupta II mahärājādhirāja śrìkramādityaVainyagupta bhagavān mabādevapādānudhyāta

Already from a first comparison and as discussed below it becomes clear that Xuanzang does not reflect the dynastic lineage as given in the inscription $s^{30}$ when presenting the parampara of the Gupta kings. The 'unhistorical' treatment of the Guptas is evident when the Chinese monk places the first king, Sakrāditya, not long after the time of the Buddha's parinirvanna (fo niepan hou wei jiu 佛涅槃 後未久). Such a dating is, of course, impossible because such early archaeological evidence at Nālandā does not exist, but also in the light of the fact that a ruler name Śakrāditya is not known before the Guptas. $^{31}$

As has been observed very early by scholars, the second membra of the royal names or epithets in Xuanzang's list, -äditya and -gupta, clearly refer to the Gupta rulers. However, as Michael Willis states correctly, the obsession of historians to identify each of Xuanzang's kings with one Gupta ruler has led to rather questionable historical results and has created some mess in the reconstruction of the Gupta lineage. ${ }^{32}$ My suggestion is that one should, instead, keep the two

30 Ji, Datang Xiyu ji jiaozhu, 755, note 2.

31 The name (Śrī) Śakrāditya on a seal found at Nālandā definitely has nothing to do with Xuanzang's king. Sastri, Nalanda and its Epigraphic Material, 38.

32 Willis, 'Later Gupta History', 140: 'The link between the coins, seals and Xuan Zang's testimony is just the kind of connections historians love to make. And it is, equally, just the kind of connections they are loath to renounce'. One example, among many, is Raychaudhuri, Political History of Ancient India, 526, who uncritically relies on Xuanzang and creates a dynastic family tree from conflating inscriptions and Xuanzang's data. See similarly Jayaswal, An Imperial History of India, 34-35; Gokhale, 'Buddhism in the Gupta Age'. 
strands of sources separated and neither force Xuanzang's narrative nor the inscriptional lineage into the Procrustes bed of the respective other. In Xuanzang's case, I would work with the hypothesis of an 'idealized' lineage of rulers ${ }^{33}$ and would focus on the explanation of the irregularities of the names-the deficiencies in transliteration and translation (see below) - and the particularities of his narrative before comparing it with other sources.

Some historical links may be made, however, but strictly for the purpose of understanding how the Gupta lineage as reflected in the inscriptions transformed into the one reported by Xuanzang, and not the other way around. A starting point is $\mathrm{Bu}(\mathrm{d})$ dhagupta who can, without too many problems, be identified with the Gupta ruler of the same name. ${ }^{34}$ Budhagupta's father, however, was Purugupta ${ }^{35}$ and not Śakrāditya/Kumāragupta I (mahendrāditya) who was Budhagupta's grandfather. The epigraphic and numismatic evidence does not refer to such a ruler name but it has since long been observed that Kumāragupta I uses the name Mahendrāditya in the legends (biruda) on his coinage. Since Śakra and (Mahā-)Indra both are the names for the same god-Śakra rather being used in a Buddhist context-Śakrāditya ${ }^{36}$ has been taken as a variant of the biruda Mahendrāditya and been identified with Kumāragupta I.

The name of Budhagupta's successor in Xuanzang's lineage is a Tathāgatagupta, and again, such a name does not appear at all in any of the historical sources. If we give up the idea that Xuanzang presents us with a historically sound dynastic lineage, but rather a 'buddhisized' and idealized one in which all kinds of amalgamation or exchange processes could have happened, Tathāgatagupta may

33 This includes truncation of longer lineages; in Tārānātha's history the Gupta dynasty is reduced to one ruler, Candragupta. See Chattopadhyaya, Tärānātha's History of Buddhism in India, 123.

34 On the historical Budhagupta, see Bakker, The World of the Skandapurāna, 28-29.

35 Willis, 'Later Gupta History', 142.

36 See, for example, Heras, 'The Royal Patrons of the University of Nalanda', 3-4, while Sastri, 'Nālandā’, 154, argued against such an identification. 
have been a phantasy-produced 'offspring' of Buddhagupta, both names meaning semantically the same: 'Protected by the Buddha/by the Tathāgata' and originally referring to the same ruler, Budhagupta. One can speculate if the source(s) which Xuanzang used-or Xuanzang himself_-mixed up Tathāgatagupta with Bālāditya, who ranges so prominently in Xuanzang's report, in the Mañjuśrimülakalpa and in the (Chinese) Biography of Vasubandhu as a Buddhist king because of his Buddhist name.

Another problem is the last Gupta king mentioned by Xuanzang, Vajra. First of all, the name does not seem to be complete but is missing a second membrum, probably the regular final element -gupta. But even if we restore to *Vajragupta no source mentions this name. The only guess I can offer to address this riddle is that Vajra(gupta) may be a corrupt form of the historical Vainyagupta.

It is evident that in Xuanzang's narrative Vajra's predecessor, Bālāditya, plays the major role. The identification of this Bālāditya, on whom will be the focus of the rest of this paper, with one of the attested Gupta rulers is problematic as Michael Willis has pointed out. ${ }^{37}$ Most scholars have identified this Bālāditya with Narasimhagupta since in the epigraphic material this king uses the same biruda. ${ }^{38}$ But if we accept for a moment that Budhagupta

37 Willis, 'Later Gupta History'. I will not discuss here the narrative of the king Bālāditya who subdued the Hūṇa king Mihirakula (Mahirakula) in the 'Record' ( $T$ no. 2087: 888b.22ff) which is difficult to reconcile with the earlier Bālāditya from the Nālandā foundation story; for a discussion of such attempts see Deleanu, The Chapter on the Mundane Path, 187ff. The defeat of Mihirakula is otherwise clearly claimed by the Aulikara ruler Yaśodharman around 532, see Bakker, The World of the Skandapurāna, 38ff.; Bakker, Monuments of Hope, 19-20. It seems that the Buddhist tradition which Xuanzang had access to either conflated two rulers with the same name Bālāditya (Sastri, Nalanda and its Epigraphic Material, 73) or ascribed the protection of the dharma against the barbarian Mihirakula anachronistically to the earlier Gupta ruler.

38 But see Jayaswal, An Imperial History of India, 54-55, who identifies this king as the late Gupta ruler, Bhānugupta, whose epithet was Bālāditya as well. Bālāditya was the name of several rulers after the Guptas, for example, the king men- 
and Tathāgatagupta are referring to the same historical ruler, Xuanzang's Bālāditya would then rather be Kumāragupta II and not Narasimhagupta, ${ }^{39}$ who ruled before Budhagupta, and this could stand despite the fact that Kumāragupta II in the inscriptions has different birudas.

Bālāditya is the only of the Gupta kings named by Xuanzang who develops considerable construction activities outside of the complex monastery and builds a huge temple for an image of Śàkyamuni Buddha. ${ }^{40}$ It seems as if this point is supported, even in some detail, ${ }^{41}$ by the inscription from the reign of king Yaśovarmadeva found at Nālandā, which highly praises the temple $(\operatorname{pra} \bar{s} \bar{a} d a)$ built for the image of Śākyamuni Buddha (Śauddhodani) by king Bālāditya as outstanding in the world. ${ }^{42}$

tioned in the eighth century Deo Bavanark inscription of Jivitagupta II (Bakker, The World of the Skandapurāna, 67). For a non-royal Bālāditya in the reign of Mahīpāladeva (r. 988-1038) see Sastri, Nalanda and its Epigrapbic Material, 107.

39 Insisting on this identification is Heras, 'The Royal Patrons of the University of Nalanda', who is, as far as I know and compared with other scholars, the only author going the opposite interpretative direction by 'pressing' the inscriptional and numismatic date into the Procrustes bed of Xuanzang's description. See also Sastri, 'Nālandā', 152.

$40 T$ no. 2087: 924a.29ff: 觀自在菩薩精舍北有大精舍，高三百餘尺，婆羅阿 迭多王之所建也，莊嚴度量及中佛像，同菩提樹下大精舍. ('To the north of the temple of the bodhisattva Avalokiteśvara is a great temple, more than three hundred $c h i$ high [and] built by king Bālāditya; its ornaments and size and the Buddha image inside are the same as that of the great temple underneath the bodbi tree'.) The importance given to this temple by Xuanzang is reflected by the fact that the description is also included in Huili's 'Biography', T no. 2053: 238b.23ff.

41 Xuanzang equals temple and image with those at Bodhgayā, and the inscription seems to do the same when it speaks of the statue as a 'victor residing on the diamond seat' (... vajrāsanastho jina ...): Sastri, Nalanda and its Epigraphic Material, 80, line 19 of the inscription.

42 Sastri, Nalanda and its Epigraphic Material, 79, line 8-9: Atrāsa[bya] parākramapranayinā jitvākhilān vidviṣo V[B]ālādityamahānrpena sakalam bhuktvā ca bhümaṇdalam / prāsādaḥ sumahān ayam bhagavatạ̣ Śauddhodhaner 
The importance of Bālāditya in the Buddhist pool of information from which Xuanzang obviously drew is also reflected in Huili's biography of the master: when Xuanzang had passed a test of his knowledge of the Yogācāra teaching by Sinlabhadra, he was housed in the fourth floor of a multi-stored structure built by king Bālāditya, ${ }^{43}$ probably inside of the monastery, which once was inhabited by the eminent Buddhist master Dharmapāla. ${ }^{44}$ The building obviously reflected the appreciation the monastic community had for their most prominent royal patron.

There is another important point I should make with respect to the religious affiliation of the rulers. Despite the fact that under the Guptas the major public and imperial religion was Hindu, ${ }^{45}$

adbhutaḥ Kailāsáabibhāvecchayeva dhavalo manye samutthāpitaḥ ('This large, magnificent and shiningly white temple for the venerable son of Suddhodana (i.e. the Buddha) was erected by the great king Bālāditya, desiring unrivaled power, after he had been victorious over all enemies and had enjoyed [the rule over] the circle of the earth, as it was meant [to be constructed] with the desire to supersede [mount] Kailāśá. [translation by Deeg]). It should be pointed out that the rather peculiar attribute dhavala, 'shining white', may be an allusion to a Gupta queen called Dhavalā, wife of a king V[B]ālāditya who both are referred to in the Sārnāth inscription of Prakatāalitya: Deleanu, The Chapter on the Mundane Path, 191.

43 A seal found at Nālandā speaks of a Bālāditya-gandhakudīi: Sastri, Nalanda and its Epigraphic Material, 38; this could well refer to the 'pavilion' (chongge 重 閣) inhabited by Xuanzang.

44 Tno. 2053: 237a.19ff.

45 As a typical, slightly contradictory, statement on the religious situation under the Gupta R.S. Sharma, India's Ancient Past, 243, may be quoted: 'Buddhism ceased to receive royal patronage during the Gupta period. Fa-hsian gives the impression that this religion was flourishing, but in reality it was not as important during the Gupta period as it had been in the days of Ashoka and Kanishka. However, some stupas and viharas were constructed, and Nalanda became a centre of Buddhist education'. To resolve this contradiction Sharma emphasizes: 'The Gupta kings followed a policy of tolerance towards different religious sects. We find no example of persecution of the followers of Buddhism and Jainism. 
a point can be made that this does not mean that there was no support for Buddhism under their rule. ${ }^{46}$ In fact, Hans Bakker has pointed out the religious tolerance under the dynasty. ${ }^{47}$ The inscriptions of Budhagupta at least reflect some royal support for the religion. ${ }^{48}$ Narasimhagupta, according to a later inscription, donated a temple to Nāland $\bar{a}^{49}$ - which admittedly would make him again a candidate for Xuanzang's Bālāditya. Of the later Gupta kings, Viṣnugupta supported Buddhism as shown by an inscribed seal from Nālandā, and Vainyagupta approved of the donation to a Buddhist ācārya. ${ }^{50}$

Xuanzang's information may originate from an unpreserved Buddhist historiography, ${ }^{51}$ possibly related to Nālandā, which created an idealized narrative of a direct Gupta patronage reflecting the historical memory of the monastery's foundation, in several phases, under the rule of this dynasty, which does not necessarily stick to historical reality but is more interested in presenting a continuous royal patronage of the monastery by one of the most famous Indian dynasties. For comparison, one may look at the narrative of the

This was also due to the change in the character of Buddhism which had come to acquire many features of Brahmanism and Hinduism' (244).

46 See, for example, Willis, 'The Dhanesar Kherā Buddha'; see also Narain, 'Religious Policy and Toleration in Ancient India', 38ff.

47 Bakker, 'Royal Patronage and Religious Tolerance'; see also Narain, 'Religious Policy and Toleration in Ancient India', 34ff.

48 See also the royal seal of Budhagupta from Nālandā: Sastri, Nalanda and its Epigraphic Material, 64.

49 Narain, 'Religious Policy and Toleration in Ancient India', 43. One seal with Narasiṃhagupta's pedigree has been found at Nālandā: Sastri, Nalanda and its Epigraphic Material, 65.

50 Narain, 'Religious Policy and Toleration in Ancient India', 44. For a Vainyagupta seal from Nālandā see Sastri, Nalanda and its Epigraphic Material, 67.

51 Willis, 'Later Gupta History', 141, assumes that a text like Vasubandhu's biography and 'oral traditions which accompanied them' was the basis of Xuanzang's record. I would rather assume that Xuanzang had access to a Nālandā record similar in its Buddhist historiographical tenets to the Mañjuśrimülakalpa. 
Gupta dynasty in another Indian sources, the Mañjuśrimülakalpa, a text from the eighth century. The fifty-third chapter (parivarta) of this text is called Rājavyākaranaparivarta, 'Chapter of the Prophecy of Kings', whose historical value is overestimated by Jayaswal in the typical hyper-positivist way:

The author or the authorities of the MMK had a true history of the Gupta times. The account, where verifiable, is very correct. It is sober and fuller.... There are some most valuable details which illuminate the confused portions of the Gupta history and help us in coming to a decision on debated and doubtful points. It is not a matter of small satisfaction to recover an actual Indian record in the form of a written history of the Great Gupta epoch. The character-estimate of the Gupta emperors by the Buddhist historian is very valuable and it is fortunately very sound even when the kings were not Buddhists. The account really constitutes true history. ${ }^{52}$

This high praise may be brought back to the ground by Michael Willis' assessment of the text's historical value:

A second source [beside the Pāli vamsas] which occupies a problematic place in the historiography of the Gupta period is the Mañjusirimülakalpa.... The agendas of the text, one hardly needs to say, were substantially different from those of modern historians. We must also note that the Mañjusrimülakalpa, which is consciously cryptic, has acquired historical meaning in the modern sense only through inscriptions and coins. The flow of information in the other direction, i.e. from text to epigraphic and numismatic material, is so contested and problematic that it can only be judged as consistently unreliable for chronological and genealogical purposes..$^{53}$

While in general I agree with Willis' statement, I still would try to link the text not only in one direction, the epigraphic and numismatic

\footnotetext{
52 Jayaswal, An Imperial History of India, 34.

53 Willis, 'Later Gupta History', 141, note 47.
} 
material, but also with the other Buddhist sources available, one of them being Xuanzang, and would try to make sense of them as much as possible. The purpose of doing this is then not for reconstructing chronological and genealogical history, but to get insight into the otherwise lost processes of composing Buddhist historiography in the first millennium. Hardcore historians may call this 'wrong Gupta genealogies', but these genealogies still have their value, I would claim, for the understanding of how Buddhists looked at their own history in relation to the worldly power in a similar way as the Pāli vamsas or the Chinese Buddhist chronicles.

The lineage of Gupta kings in the Mañjusirimülakalpa, partly reconstructed and not completely clear, is: ${ }^{54}$

$$
\begin{gathered}
\text { Samudra(-gupta)—Vikram(āditya)—S(kandagupta)— } \\
\text { Mahendrāditya (Kumāragupta I)—Bāl(āditya)—Kumāra(gupta)— } \\
\text { U(kārākhya) (= Budhagupta? }{ }^{55} \text { or Viṣnugupta)—Deva(gupta) }
\end{gathered}
$$

There are some interesting parallels between the Datang Xiyu ji and the Mañjusimülakalpa which may shed some light on the sources of Xuanzang's report. The most striking one is that, like Xuanzang's report, the Mañjuśrimülakalpa highlights one king as particularly supportive of Buddhism, Bālādhyakṣa - not the king mentioned as ruling the East afterwards, Bālākhya, 'the one called Bāla' whom Jayaswal $^{56}$ identifies with the previous Bālādhyakșa, but who is, according to the text, a reincarnation of the first Bālāditya-who can be equated with Xuanzang's Bālāditya, while the other kings are more or less mentioned in passing:

Listen carefully [about] the intermediate well-dwelling (257) kings

54 Modified from Jayaswal, An Imperial History of India, $33 \mathrm{ff}$.

55 According to Jayaswal, An Imperial History of India, 38-39, whose manipulation of the Gupta lineage is, however, not necessary since the Mañjuśrimülakalpa is not much more historical than Xuanzang's list.

56 Jayaswal, An Imperial History of India, 33.

57 Samāsvāsā? 
in the middle period following the middle $d h a r m a^{58}$ in the infinite yuga. Both the king having the name [part] Samudra (Samudragupta) and [the king] Vikrama (Vikramāditya = Candragupta II) [are] famous; [then] the best of rulers and kings, the most eminent with the syllable sa- (Skandagupta) as the first [part of his name], focused on the highest [goal]. The one who has the name [part] of the 'Lord of the gods' in his name (devarāja = Mahendr[āditya $=$ Kumāragupta I?) will be, in the most inferior of the yugas, the best king, will be wise and fond of the dharma. His offspring, the overseer of power (Bālādhyakșa = Bālāditya), will be devoted to the blissful teaching [of the Buddha] and will then, without any doubts, make the whole eastern earth reaching to the ocean adorned and embellished with caityas; monasteries, monastic dwellings, ponds, gardens with lofty pavilions ${ }^{59}$ will always be [there]. The noble one will then build a passage across the river [Gangā], the builder of bridges, so that he may venerate the images of the Teacher, purified by him, and cause [them] to be venerated. After having ruled without opponent and without resistance, the protector of the earth, the king, may live for thirty years and thirty days and [then] come forth [as a monk]. Then the king may kill himself, in contemplation ${ }^{60}$ and stunned, tormented by the pain [about the loss of] his son and taking refuge to the practice of asceticism. And then, after his death, he avoided the hells, dwelling in three and one heavens, after his body was thrown out of a hellish [form of] existence he may go to heaven forever. The world of the blessed gods is called the 'Pure Abode' (Śuddhāvāsa). The divine king may be there with a purified and deep inclination to awakening (bodbi). And having been reborn hundreds, thousands of times in divine bliss he will be again reborn as a human being, closer to being a Buddha [than before]. Through the deeds he had done, [he] then [was born] among other reborn living beings in the city

58 Jayaswal, An Imperial History of India, 33, translates this as: 'Listen about the Medixval and Madhyadeśa kings (...) who will be in a long period emperors (...) and who will be confident and will be followers of the via media'.

59 Udyānā mandavakām = udyānān mandapakān?

60 Dhyāyantah as a wrong vowel-stem present participle instead of dhyāyān? 
called Ujjayanī among the people of Kālava. There [he will be] a merchant, overseeing the coming [and going] ${ }^{61}$ who has a lot of wealth. In a time in which there are no Buddhas, an empty world without places [for Buddhas] Pratyekabuddhas with a lot of magical power [will] dwell in that world, will act for the sake of the bliss of the living beings on the great earth. After they reach the city of Ujjayani [they] enter it for the sake of alms-begging. Walking on their path the great-spirited ones appear ${ }^{62}$ on the main road. When the merchant then looks towards the wise $\operatorname{man}^{63}$ he invites [him] to eat and may lead him to his house. After having led [him to his house] he may quickly invite the wise man [to take] a seat [saying]: 'Oh Venerable Ones, may you form an assembly! The time for food has come'. And the great-spirited was silent and did not speak a word, lowered his alms-bowl in front of the merchant the whole time. Thereupon the merchant, recognizing the gesture, may become wise and fill the alms-bowl with all kinds of food and give [them] carefully with his own hand. After they have taken [the food] they go everywhere in the sky, are seen like garlands of lamps, their shapes clinging at the firmament. But he, his hair risen and full of agitation, falls to the ground, his mind twisted by the [display] of magical power. And he then made a vow as if in conversation [with himself]: ${ }^{64}$ 'It is through that root of merit that [this will] be obtained by me from today [in the future]'. Those best of wise men may become a best, unsurpassed Buddha, [while the merchant] may then, [after] ten thousand of births, become a wheel-turning king. But then this [king], after briefly having attained the body among sixty of kotis of heavenly residents [as] declared [before] and having abandoned the blissful birth among

${ }^{61}$ I am not sure how to separate tatrāyanimukbyaḥ; I tentatively take āyanī in the translated meaning.

${ }^{62}$ I take the corrupt (reading?) avataratat as a finite verb, $3 \mathrm{rd} \mathrm{pl}$.

63 vānyājeyas tustadā saiva duṣtvā tu saṃmukhām munim. This and some of the following sentences-see the constant switch between singular and plural when referring to the Pratyekabuddhas-seem completely corrupted to me; I have translated as well as I could make sense of it.

${ }^{64}$ pravyāhāravabha > pravyāhārabhava? 
the heavenly residents, [according to] another willful [decision] may attain rebirth among human [beings] here [in this world], and continuously his rebirth is here [in this world] in a royal family. He will be king with the name [part] Bāla in the eastern regions. For thousands of rebirths this noble king obtained short [but] irreversible bliss and the final omniscience. Thus considering [it] manifold there were many lucky coincidences such as: "Who thus may request the acts of veneration for the Teacher (i.e. the Buddha) and commit oneself to the best and suitable [ways of] liberation on the path to enlightenment?' After him there will be a king of the Gauda (i.e. Bengal), called by one name part Kumāra, ${ }^{65}$ and he also will be full of the dharma [which] leads to happiness. After him a noble one will be widely known as having the syllable $U$ as part of his name. After that, separation [of the different parts of the empire] from each other was initiated. Since [they] had [that] great separation these Gaudas [became] full of brutal thoughts. Then a king of Magadha with Deva as part of his name will be remembered. ${ }^{66} 67$

${ }^{65}$ Kumāragupta of the Late Guptas. Cf. Thaplyal, Inscriptions of the Maukharīs, Later Guptas, Puspabbütis and Yasovarman of Kanauj, 38.

${ }_{66}$ One of the two Devaguptas of the Late Guptas, on whom see Thaplyal, Inscriptions of the Maukharis, Later Guptas, Puspabbütis and Yasovarman of Kanauj, 42-43, or 46 (Devagupta II)?

${ }^{67}$ Online version by GRETIL of the edition Śāstri, Mañjuśrimūlakalpa, 593: madbyakāle samāsvāsā madhyamā madhyadharminặ; anante va yuge nrpendrā șrnu tattvatah. 594. samudräkbyo nrpaś caiva vikramaś caiva kìrttitah, mahendranrpavaro mukbya sakārādyo matạ param. 595. devarājākbyanāmāsau ...... yugādhame; nirddhākhye nrpaḥ śresthaḥ buddhimān dharmavatsalah. 596. tasyāpy anujo balādhyakșạ̣ sāsane ca hite rataḥ; prācīm samudraparyantām caityālaìkrtaśobhanām. 597. karisyati na sandehạ krtsnām vasumatīm tadā; vihārārāmavāpiśs ca udyānā mandavakām sadā. 598. kariṣati tadā śrimām saìkramām setukārakaḥ; śāstur bimbān tadā pūjet tatprasannāmśs ca püjayet. 599. krtvā rājyam mahīpālo nihsapatnam akanțakam; jīved varșām sațtrmśat tṛ̣sáham pravraje nrpah. 600. tato 'tmānam ghātayed rājā dhyāyantah sampramūrcchitab; putrasokābhisantaptah yativrttisamāśrtah. 601. tato 'sau bhinnadehas tu narakebhyo 'papadyata; trịni ekam ca divasāni ușitvā narakam 
gatim. 602. deham utsryya divim gacchet sadā nrpaḅ; devānām sukrtinām lokạ̣ suddhāvāsa iti smṛtạ̣; devarājā bhavet tatra suddhātmā bodhinimnagah. 603. śataśạ sahasraśaś caiva anubhūya divìn sukham; punar eva mānusyam prāpya buddho bhūyo bhavāntare; tenaiva kāritam karma anyajanmeșu dehinām. 604. purìm ujjayanìm khyātā kālavānām jane tadā; tatrāyanìmukhyaḥ vanijo yo mahādhanaḥ. 605. buddhānām asambhave kāle śünye loke nirāspade; pratyekabuddhā loke 'smim viharanti mabarddhikāḥ. 606. sattvānām hitakāmāya vicaranti mahìtale; purī ujjayin̄i prāpya praviștā piṇdacārikā; vargacāriṇo mahātmānaḥ rathyāyāmavataratat. 607. vānyājeyastustadā saiva duștvā tu saṃmukhām munim; nimantrayāmāsa tadā bhaktena svagṛham caiva nayet tadā; nìtvā munivarām kșipramāsanena nimantrayet. 608. sanghībhavadbva bhavatah bhaktakālo 'yamupasthitah; te 'pi tūṣnìm mahātmāno na vācām bhāșire tadā. 609. pātram ca nāmayāmāsa vānije yasya sarvadā; vanijā ingitajñāśs ca buddhimanto bhavet tadā. 610. pātram ca pürayāmāsa vividhākārabhojanaiḥ; tadāsau svahastenaiva teșām prāyaccha yatnatah. 611. grhītvā tu tatạ sarve prajagmuḥ sarvato nabham; dīpamāleva dṛsyante vyomamūrttisamāśritāḥ. 612.

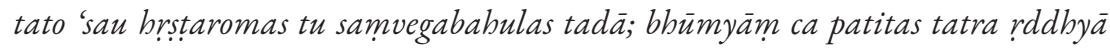

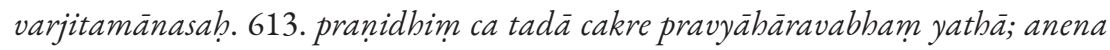
kuśalamūlena yanmayā prāptamadyatah. 614. eșā munivarā magra bhaved buddho by anuttaraḥ; dasajanmasahasrāni cakravarttī tadā bhuvi. 615. tato 'sau vyuktadehas tu koțiṣaștidivaukasām; anubhūya ciram saukhyam tyaktvā janma divaukasām. 616. mānuṣānām tad̄̄ janma prāpnuyāt paravaśā iha; tasya rājakule janma bhavatīha tu sarvadā. 617. bālākhyo nāma 'sau nrpatir bhavitā pürvadeśakah; ājanmasahasrāni cirasaukhyam anāvrtam; prāpnuvanti yā nrpatị̣ śrimām sarvajñatvam ca paścimam. 618. evam bahuvidham matvā sampado vipulās tathā; ko nu kuryāt tadà sástuh pūjanādhyeșañāns tathā; kārāmśs ca śreyasìm yuktām bodhimārgaviyojanìm. 619. tasyāparena nrpatì gaudānām prabhaviṣnavah; kumārākhyo nāmatạ proktạ̣ so 'pi ratyantadharmavām. 620. tasyāparena śrimām ukārākhyeti viśrutah; tatạ pareña viśleṣa teṣām anyonyatesyate. 621. mahāvisleșaña by ete gaudā raudracetasaḅ; tato deva iti khyāto rājā māgadhakah smrtah. 
The parallels between the two Buddhist sources are obvious. Both Xuanzang and the Mañjuśrimülakalpa not only make Bālāditya, to whom they dedicate the longest passage in their description of rulers, a supporter of Buddhism but also agree in having him become a monk, or rather a novice. The Mañjuśrimülakalpa even goes so far to have the king be reborn after several rebirths with obviously the same name, Bālāditya, thus stretching the timeline of the Guptas in a similar way as Xuanzang's lineage does it backwards in the case of Śakrāditya.

The strong support of Buddhism through the king Bālādityawhoever the historical ruler figure behind this name may have been originally-is also particularly highlighted in another Buddhist narrative, in the biography of Vasubandhu, Posoupandou fashi zhuan 婆數槃豆法師傳 [Biography of the dharma master Vasubandhu], translated into Chinese by Paramārtha/Zhendi 真諦 (499-569). Here, Bālāditya is the son of Vikramāditya (T no. 2049: 189c.21-22 Bikeluomoazhiduo 楿柯羅摩阿祑多/*bjit-ka-la-ma-Pa-drit-ta, translated as Zhengleri 正勒日, 'Pure-Force-Sun'), who rules in Ayodhyā (Ayushe 阿緰闍/*2a-juă-dzia: Pkt. Ayujjhā?) and supports the master Vasubandhu by giving him three lakșa (luosha 洛沙/*lak-ş:) of gold which Vasubandhu uses to build three monasteries, one for nuns, one for the Sarvastivādin, and one for followers of the Mahāyāna (T no. 2049: 190b.2ff.). Vikramāditya's son and crown prince Bālāditya temporarily becomes a novice or monk (shoujie 受戒, Skt. upa-sam-rpad-) $)^{68}$ before he ascends the throne himself, whereupon his mother becomes a nun (chujia 出家, Skt. pra-Vvraj-):

68 Dalia, 'Biography of Dharma Master Vasubandhu', 49, wrongly translates shoujie as 'to receive the Vinaya'. Very strangely, Takakusu, 'A Study of Paramārtha's Life of Vasubandhu', 44 ('Takakusu, 'The Life of Vasubandhu by Paramārtha', 288: 'receive his (i.e. Vasubandhu's) instructions'), did not recognize the technical nature of both terms referring to ordination: '[Vikramāditya] sent his Crown Prince (Bālāditya) to Vasubandhu to learn Buddhism, and the Queen too became one of his disciples'. See also Deleanu, The Chapter on the Mundane Path, 187. 
King 'Pure-Force-Sun's' (Vikramāditya) crown prince's name was Poluozhidiye. Poluo is translated as 'new', [and] zhidiye is translated as 'sun'. ${ }^{69}$ Originally the king had ordered the crown prince to go to the dharma master [Vasubandhu] and to take the precepts. The royal consort left the household and also became the dharma master's disciple. When the crown prince later ascended the throne, mother and son both asked the dharma master to stay in the kingdom of Ayodhyā and to accept their offerings. The dharma master accepted. ${ }^{70}$

The conclusion one may draw from all of this is that Xuanzang's story of Bālāditya becoming a novice (śrammanera) seems to be based on a Buddhist historiographical narrative about certain rulers of the Gupta. Xuanzang's story is more Nālandā-specific and explains how the tradition of Nālandā monastery ranking novices by their real age rather than their 'monastic' years came into being, a point which is not confirmed by other sources.

Taking the Buddhist sources, Xuanzang, the Mañjusrimuilakalpa and the biography of Vasubandhu, together it looks as if they reflect a Buddhist view of Gupta history that focuses on Bālāditya as a fervent Buddhist king who may be an amalgamation of different

69 There are some problems with the transliteration of the name and its (inserted) explanation. First of all the second element (-äditya) in Poluozhidiye 婆 羅袟底也 $/{ }^{*} b a-l a-d r i t-t \varepsilon j '-j i a$, differs from the corresponding name part of the royal father, azbiduo 阿袟多/*Pa-drit-ta. The analysis of the name shows some flaws: Skt. bāla does not mean 'new' (xin 新), but Hans Bakker (verbal communication) reminds me that Bālāditya in the sense of the 'youthful sun, raising sun' may justify the interpretation of bāla as 'new (= young)'. See also Deleanu, The Chapter on the Mundane Path, 190. What weighs more, however, is that the compositional structure of the Skt. name is falsely analyzed by not transliterating the initial $\bar{a}$ of $\bar{a}$ ditya, and the syllable $d i$ 底 $/{ }^{*} t \varepsilon j$ ' is either superfluous or represents a proclitic pronunciation ${ }^{*} \bar{a}$ ditiya.

70 正勒日王太子, 名婆羅袟底也. 婆羅譯為新, 袟底也譯為日. 王本令太子就 法師受戒. 王妃出家，亦為法師弟子. 太子後登王位，母子同請留法師住阿緰闍 國, 受其供養. 法師即許之 (T no. 2049: 190b.18ff). 
Gupta rulers. This may also explain why the position of Bālāditya in the Gupta lineage is not identical in the different Buddhist sources: Xuanzang makes him the grandson (or son, in case Budhagupta and Tathāgatagupta are referring to the same ruler) of Budhagupta, in the Mañjuśrimūlakalpa Bālāditya is the son of Kumāragupta and father of Budhagupta, and in the 'Life of Vasubandhu' the king is the son of Vikramāditya (Candragupta II). ${ }^{71}$ Thus none of these lineages agrees with the lineage reconstructed from the inscriptions nor do they with each other, but for the purpose of the Buddhist narrative historical correctness in this respect probably was not the most important part of the story. What unites the Buddhist sources is that they all give a king called Bālāditya a prominent role in the Gupta lineage of protecting the Buddhist dharma and saigha, a role which cannot be ignored.

So are we entitled to assume that the silence of the inscriptions on such an important king as Bālāditya overwrite the Buddhist voice, including Xuanzang? I am tempted to take a middle stance and claim some historical reality behind the fragments of a Buddhist narrative about a Gupta king Bālāditya which is just not reflected in the inscriptions, but whose historical identity may be unearthed at some point in the future with a higher degree of certainty as yet. For the time being, however, the comparison of sources clearly speaks in favor of Xuanzang as a relatively reliable witness of a Buddhist historiographical tradition which linked the Gupta kings in general, and Bâlāditya in particular, with the sponsorship and patronage of the greatest Buddhist monastery in India at the time of Xuanzang's visit.

71 For a discussion of the identity of Bālāditya in the Vasubandhu 'tradition', see Anacker, Seven Works of Vasubandhu, 8ff., who suggests that bālāditya is a title given to Gupta crown princes (yuvarāja) and identifies Bālāditya with Govindagupta, the oldest son of Candragupta II/Vikramāditya. 


\section{Bibliography}

Abbreviations

T Taishōshinshū daizōkyō 大正新脩大蔵経. See Bibliography, Secondary Sources, Takakusu and Watanabe, eds.

\section{Primary Sources}

Ayu wang zhuan 阿育王傳 [Skt. *Aśokarājâvadāna; Biography of King Aśoka]. Translated by An Faqin 安法欽 (fl. 281-306) in 306. T no. 2042, vol. 50.

Datang Da Ci'en si sanzang fashi zhuan 大唐大慈恩寺三藏法師傳 [Biography of the Tripitaka dharma master of the Great Cien Monastery of the Great Tang (Dynasty)]. 10 juan. By Huili 慧立 (615-675?) and Yancong 彥悰 (ca. 650-688). T no. 2053, vol. 50. Datang Xiyu ji 大唐西域記 [Great Tang Record of the Western Regions]. 12 juan. By Xuanzang 玄奘 (602-664) and Bianji 讋機 (?-649). $T$ no. 2087, vol. 51. References are also made to Ji et al (coll. and annot.).

Da zhuangyan lunjiing 大莊嚴論經 [Skt. *Sütrâlamkāra-śāstra]. 15 juan. Translated by Kumārajīva (344-413) between 402-412. T no. 201, vol. 4.

Dacheng ru lengjia jing 大乘入楞伽經 [Skt. Laìkāvatārasūtra]. 16 juan. Trans. Śikșānanda (Shicha'nantuo 實叉難陀; 652-710) in 700. T no. 672, vol. 16 .

Jinglü yixiang 經律異相 [Differences and Similarities in the Sütras and Vinayas]. 50 juan. Compiled by Baochang 寶唱 (of sixth century) et al. in 516. T no. 2121, vol. 53

Posoupandou fashi zhuan 婆藪槃豆法師傳 [Biography of Dharma Master Posoupandou =Vasubandhu]. 1 juan. Translated by Zhendi 真諦 (Paramārtha; 499-569). T no. 2049, vol. 50.

Shijia fangzhi 釋迦方志 [Record of the Regions of Śākya(muni)]. 2 juan. By Daoxuan 道宣 (596-667) in 650. T no. 2088, vol. 51. 


\section{Secondary Sources}

Anacker, Stefan. Seven Works of Vasubandhu, the Buddhist

Psychological Doctor. Delhi: Motilal Banarsidass, 2005.

Bakker, Hans T. Monuments of Hope, Gloom and Glory: In the Age of the Hunnic Wars-50 Years That Changed India (484534). 24th Jan Gonda Lecture. Amsterdam: J. Gonda Fund Foundation of the KNAW, 2017.

— . 'Royal Patronage and Religious Tolerance: The Formative Period of Gupta-Vākāțaka Culture'. Journal of the Royal Asiatic Society 20, no. 4 (2010): 461-75.

— 'A Theatre of Broken Dreams. Vidiśā in the Days of Gupta Hegemony'. In Interrogating History: Essays for Hermann Kulke, edited by Martin Brandtner and Shishir Kumar Panda, 165-87. Delhi: Manohar, 2006. . The World of the Skandapurana. Northern India in the Sixth and Seventh Centuries. Supplement to Groningen Oriental Studies. Leiden/Boston: Brill, 2014.

Chattopadhyaya, Lama Chimpa Alaka. Tārānātha's History of Buddhism in India. Edited by Chattopadhyaya Debiprasad. Delhi: Motilal Banarsidass, 1990.

Dalia, Albert A. 'Biography of Dharma Master Vasubandhu. Translated from the Chinese of Paramārtha (Taishō Volume 50, Number 2049)'. In Lives of Great Monks and Nuns, edited by Li Rongxi, et al., 31-53. Berkeley: Numata Center for Buddhist Translation and Research, 2002.

Dandekar, R.N. A History of the Guptas. Poona Oriental Series 76. Poona: Oriental Book Agency, 1941.

Deeg, Max. 'The Political Position of Xuanzang: The Didactic Creation of an Indian Dynasty in the Xiyu ji'. In The Middle Kingdom and the Dharma Wheel: Aspects of the Relationship between the Buddhist Samgha and the State in Chinese History, edited by Thomas Jülch, 94-139. Leiden/Boston: Brill, 2016. - 'Setting the "Records" Straight: Textual Sources on Nālandā and their Historical Value'. In Record, Recoveries, Remnants and Inter-Asian Interconnections: Decording Cultural Heritage, edited by Anjana Sharma, 105-59. Singapore: ISEAS Yusof Ishak 
Institute, 2018.

—. "Show Me the Land Where the Buddha Dwelled..."-

Xuanzang's "Record of the Western Regions" (Xiyu ji): A

Misunderstood Text?' China Report 48 (2012): 89-113.

- 'Writing for the Emperor-Xuanzang between Piety,

Religious Propaganda, Intelligence, and Modern Imagination'. In Pāsādikadānam: Festschrift für Bhikkhu Pāsādika [Pāsādikadānaṃ: Festschrift for Bhikkhu Pāsādika], edited by Martin Straube, Roland Steiner, Jayandra Soni, Michael Hahn, Mitsuyo Demoto, 30-60. Marburg: Indica et Tibetica Verlag, 2009.

Deleanu, Florin. The Chapter on the Mundane Path (Laukikamārga) in the Srāvakabbümi: A Trilingual Edition (Sanskrit, Tibetan, Chinese), Annotated Translation and Introductory Study, Volume I: Introductory Study, Sanskrit Diplomatic Edition, Sanskrit Critical Edition. Studia Philologica Buddhica, Monograph Series XXa. Tokyo: The International Institute for Buddhist Studies, 2006. Gokhale, Balkrishna Govind. 'Buddhism in the Gupta Age'. In Essays on Gupta Culture, edited by Bardwell L. Smith, 129-53. Delhi, Varanasi, Patna: Motilal Banarsidass, 1983.

Heras, H. 'The Royal Patrons of the University of Nalanda'. Journal of the Bihar and Orissa Research Society 19, no. 1 (1928): 1-23.

Hinüber, Oskar von. Das ältere Mittelindisch im Überblick [An Overview of the Older Middle Indian]. Wien: Verlag der Österreichischen Akadamie der Wissenschaften, 2001. (Österreichische Akademie der Wissenschaften, Phil.-Hist. Kl., Sitzungsberichte 467. Band, 2., erweiterte Auflage [Austrian Academy of Sciences, Phil.-Hist. Kl., Session reports 467. Volume 2, extended edition]).

Hirakawa Akira 平川彰. Bukkyō Kanbon daijiten 佛教漢梵大辭典 / Buddhist Chinese-Sanskrit Dictionary. Tokyo: Reiyukai 靈友會, 1997.

Jayaswal, K. P. An Imperial History of India in a Sanskrit Text [c. 700 B.C.-c. 770 A.D.] With a Special Commentary on Later Gupta Period. Lahore: Motilal Banarsi Dass, 1934.

Ji Xianlin 季羡林, et.al., coll. and annot. Datang Xiyu ji jiaozhu 大 唐西域記校注 [Datang Xiyu ji (Record of the Western Regions from the Great Tang [Dynasty]), Collated and Annotated]. 
Beijing: Zhonghua shuju 中華書局, 1985.

Kuwayama Shōshin. 'How Xuanzang Learnt About Nālandā?'. In Tang China and Beyond: Studies on East Asia from the Seventh to the Tenth Century, edited by Antonino Forte, 1-33. Kyoto: Italian School of East Asian Studies, 1988.

Li Rongxi. The Great Tang Dynasty Record of the Western Regions. Translated by the Tripitaka-Master Xuanzang under Imperial Order, Composed by Sramana Bianji of the Great Zhongchi Monastery. Berkeley: Numata Center for Buddhist Translation and Research, 1996.

Mizutani Shinjō 水谷真成. Dai Tō Saìki ki 大唐西域記 [Great Tang Account of the Western Regions]. 3 vols. Tokyo: Tōyō Bunko 東 洋文庫, 1999 .

Narain, A.K. 'Religious Policy and Toleration in Ancient India with Particular Reference to the Gupta Age'. In Essays on Gupta Culture, edited by Bardwell L. Smith, 17-51. Delhi/Varanasi/ Patna: Motilal Banarsidass, 1983.

Prasad, Chandra S. Nalanda, Its Mahāvihāra and Xuan Zang. New Delhi: Eastern Book Linkers, 2016.

Pulleyblank, Edwin G. Lexicon of Reconstructed Pronunciation in Early Middle Chinese, Late Middle Chinese, and Early Mandarin. Vancouver: UBC Press, 1991.

Ratnacandrajī, Jaina Muni Shri. An Illustrated Ardha-Magadbi Dictionary, Literary, Philosophic and Scientific with Sanskrit, Gujrati, Hindi and English Equivalents, References to the Texts Eे Copious Quotations. 2 vols. Tokyo: Meicho Fukyū Kai 名著普及 會, 1977. First published 1923.

Raychaudhuri, Hemchandra. Political History of Ancient India. From the Accession of Parikshit to the Extinction of the Gupta Dynasty, 7th ed. Calcutta: University of Calcutta, 1957.

Śāstri, Gaṇapati, ed. Mañjuśrimūlakalpa. Trivandrum Sanskrit Series, vols. 70, 76, 84. Trivandrum: Government Press, 1920-1925.

Sastri, Hirananda. 'Nālandā'. Journal of the Madras University 13, no. 2 (1941): 147-202.

—. Nalanda and its Epigraphic Material. Memoirs of the Archaeological Survey of India No.66. New Delhi: Archaeological Survey of India, 1942. 
Sharma, R. S. India's Ancient Past. Delhi: Oxford University Press, 2005.

Takakusu Junjirō. 'The Life of Vasubandhu by Paramārtha (A.D. 499-569)'. T'oung-Pao 5 (1904): 269-96.

'A Study of Paramārtha's Life of Vasu-bandhu; and the Date of Vasu-bandhu'. Journal of the Royal Asiatic Society 37, no. 1 (1905): 33-53.

Takakusu Junjirō 高楠順次郎, and Watanabe Kaigyoku 渡邊海旭, eds. Taishō shinshū daizōkyō 大正新脩大藏經 [Buddhist Canon compiled under the Taishō Era (1912-1926)]. 100 vols. Tokyo: Taishō issaikyō kankōkai 大正一切經刊行會, 1924-1932.

Tandon, Pankaj. 'The Succession After Kumāragupta I'. Journal of the Royal Asiatic Society 24, no. 4 (2014): 557-72.

Thaplyal, Kiran Kumar. Inscriptions of the Maukbaris, Later Guptas, Puspabbütis and Yasovarman of Kanauj. New Delhi: Indian Council of Historical Research, 1985.

Willis, Michael. 'The Dhanesar Kherā Buddha in the British Museum and the "Politische Strukturen" of the Gupta Kingdom in India'. South Asian Studies 30, no. 2 (2014): 106-15.

_. 'Later Gupta History: Inscriptions, Coins, and Historical Ideology'. Journal of the Royal Asiatic Society, Third Series 15, no. 2 (2005): 131-50. 